1979

\title{
Natural Gas Pipeline Survey Northwest Menard County, Texas Prepared for the City of Menard
}

Thomas C. Kelly

Fred Valdez Jr.

Department of Anthropology, The University of Texas at Austin

Follow this and additional works at: https://scholarworks.sfasu.edu/ita

Part of the American Material Culture Commons, Archaeological Anthropology Commons, Environmental Studies Commons, Other American Studies Commons, Other Arts and Humanities Commons, Other History of Art, Architecture, and Archaeology Commons, and the United States History Commons

Tell us how this article helped you.

This Article is brought to you for free and open access by the Center for Regional Heritage Research at SFA ScholarWorks. It has been accepted for inclusion in Index of Texas Archaeology: Open Access Gray Literature from the Lone Star State by an authorized editor of SFA ScholarWorks. For more information, please contact cdsscholarworks@sfasu.edu. 
Natural Gas Pipeline Survey Northwest Menard County, Texas Prepared for the City of Menard

\section{Creative Commons License}

\section{(c) (1) \&}

This work is licensed under a Creative Commons Attribution-NonCommercial 4.0 International License 
NATURAL GAS PIPELINE SURVEY

NORTHWEST MENARD COUNTY, TEXAS

Prepared for the City of Menard

Thomas C. Kelly and Fred Valdez, Jr.

Center for Archaeological Research

The University of Texas at San Antonio

Arcahaeological Survey Report, No. 78

May, 1979 
NATURAL GAS PIPELINE SURVEY

NORTHWEST MENARD COUNTY, TEXAS

Prepared for the City of Menard

Thomas C. Kelly and Fred Valdez, Jr.

Center for Archaeological Research The University of Texas at San Antonio Arcahaeological Survey Report, No. 78

May, 1979 
Pursuant to requirements of the E.D.A. as outlined in a letter from

the City of Menard, Texas dated Apri1 16, 1979, the Center for Archaeological Research, The University of Texas at San Antonio (UTSA) submitted a proposal for an archaeological survey of the route of a new natural gas pipeline. This proposal was accepted by the City of Menard in a letter dated April 23, and the survey was accomplished on May 1 and 2 by Thomas C. Kelly and Fred Valdez, Jr., archaeologists from the UTSA Center for Archaeological Research.

\section{SURVEY PROCEDURE AND RESULTS}

The field survey was accomplished using the U.S.G.S. Eden S.W. topographic map quadrangle (scale 1:24,000) on which the proposed pipeline was transposed from the Menard County highway map provided by the City of Menard. This was necessary because the county map was at too small a scale ( $1 "=2$ miles) and contained no topographic detail.

The southeast end of the proposed pipeline begins at an oil well .2 of a mile southwest of the Grandstaft Ranch house which is reached by following Highway 836.5 miles north from Menard, then 3.4 miles west on a county road to the Grandstaft front gate. The proposed route proceeds 4.9 miles northwest crossing the Kothmann Ranch and terminating across the county road on the Menzies Ranch at a Sun $0 i 1$ Company well near the Lackey triangulation station. This route has had an engineering survey at some time in the recent past, and enough of the flagging tape and stakes remained to provide confirmation that our survey was on the proposed pipeline-route. Beginning-and ending coordinates on the Eden S.W. topographic map (attachment) are (in UTM coordinates): 415200 meters east, 3,430,000 meters north; 411600 meters east, 3,433,920 meters north.

The archaeologists, being uncertain of the width of the pipeline easement, 
walked a 50 meter wide search pattern and checked a 71 areas likely to contain archaeological sites either side of the proposed route for 100 meters.

The route is entirely across rolling pasture land that is presently used only for cattle grazing. Grass and weeds were low providing excellent ground visibility. Broken limestone and inferior quality chert were observed throughout the area. No chert of artifact-manufacturing quality was found.

Despite the ideal survey conditions, no artifacts, debitage, hearths, or any other traces of aboriginal presence in the area were found.

The survey area contains no flowing streams and there is no indication that the one intermittent creek that crosses the route about midway has ever been anything but intermittent. Water today is obtained from wells and windmil1s. The absence of usable chert, highly important to the prehistoric aboriginal population for tool and weapon-making, is another negative factor. Based on our thorough on-the-ground survey, we are confident that there are no prehistoric or historic cultural resources that will be affected in any way by the proposed natural gas pipeline. 
ATTACHMENT

Copy of the southeast corner of the U.S.G.S.

Eden S.W. topographic map. Route of proposed natural gas pipeline is shown. Entire route examined by UTSA archaeologists. 


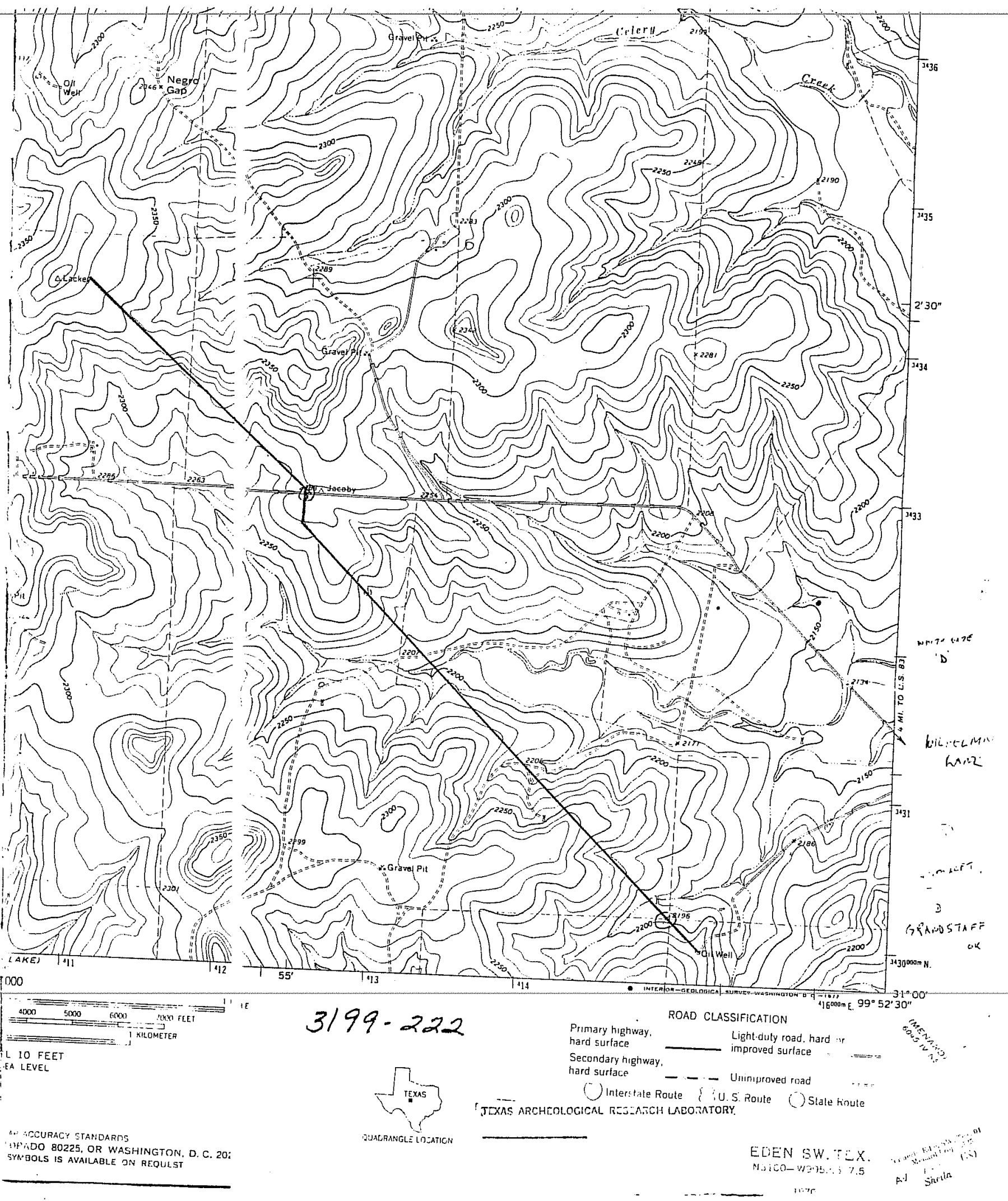

